\title{
İslamc1 Feminist Kim? Kavramların Gölgesinde Bir Kadın Söylemi
}

Ayşe Güç*

Who is Islamic Feminist? A Women's Discourse in the Shadow of Concepts

Citation/@: Güç, Ayşe, (2019). Who is Islamic Feminist? A Women's Discourse in the Shadow of Concepts, Milel ve Nihal, 16 (2), 393-417.

Abstract: This article examines Islamic feminist discourse, considering problems in conceptual usages related to this discourse, and different approaches in Muslim women's literature. One of these usages, Islamic feminism is a controversial concept that become apparent in women's studies in the 1990s. However, this concept requires to be examined since it refers to the emergence of a new discourse, and two women's literature that include different approaches. The second is Islamic feminist, a more controversial concept, for it reflects the dominant attitude of western feminism. For this reason, it is a starting point in evaluating Muslim women's literature. Many intellectual women refuse to be identified by this concept, yet they are acknowledged as Islamic feminist. Focusing on these problems, the article firstly analyses the emergence of Islamic feminist discourse. Later it refers to two main tendencies in Muslim women's literature, and evaluates its main approaches in general. With this evaluation, the article clarifies that there are differences between Islamic women's literature and secular Muslim's. The different tendencies of these women's literature reveal that Islamic women discourse has not developed in a single line of thought, rather it embraces different approaches, and thus that conceptual usages related to Muslim women's consciousness are controversial. The article finally indicates the promises and limitations of Islamic feminist discourse.

Keywords: Islamic feminism, Islamic Feminist, Islamic Woman, Feminist DisCourse, Women's Literature.

* Dr. Öğr. Üyesi, Ankara Sosyal Bilimler Üniversitesi, Sosyal ve Beşeri Bilimler Fakültesi, Sosyal Antropoloji Anabilim Dalı [ayse.guc@asbu.edu.tr] ORCID: 00000001-5115-6484. 
Atıf/C: Güç, Ayşe, (2019). İslamcı Feminist Kim? Kavramların Gölgesinde Bir Kadın Söylemi, Milel ve Nihal, 16 (2), 393-417.

Öz: Bu makale İslamcı feminist söylemi, bu söylemle ilgili kavramsal kullanımlardaki sorunları ve Müslüman kadın yazınındaki farklı eğilimleri dikkate alarak incelemektedir. Bu kullanımlardan biri olan İslamcı feminizm, 1990'। yıllarda kadın çalışmalarında yaygınlık kazanmış tartışmalı bir kavramdır. Bununla birlikte ortaya çıkan yeni bir söyleme ve farklı yönelimlere sahip iki kadın yazınına işaret ettiği için incelenmeyi hak etmektedir. İkinci kullanım ise İslamcı feministtir. Bu, batılı feminist söylemin hâkim tavrını yansıttığı için daha tartışmalı bir kavramdır. Bu sebeple Müslüman kadın yazınını değerlendirmek için başlangıç noktası olmaktadır. Pek çok Müslüman kadın düşünür açıkça bu şekilde tanımlanmaya karşı çıkmasına rağmen İslamcı feminist olarak tanınmıştır. Bu sorunları dikkate alan makale öncelikli olarak İslamcı feminist söylemin ortaya çıkış sürecini değerlendirmektedir. Daha sonra Müslüman kadın yazınındaki iki ana eğilime işaret etmekte ve bu yazındaki temel yaklaşımları ana hatları ile ele almaktadır. Böylece makale İslamcı kadın yazını ile seküler Müslüman kadın yazını arasındaki farklara da işaret etmiş olmaktadır. Bu kadın yazınları arasındaki farklılıklar İslamcı feminist söylemin tek bir çizgide gelişmediğini, aksine farklı yaklaşımlara sahip olduğunu, dolayısıyla Müslüman kadın bilinçliliği ile ilgili kavramların sorunlu kullanımını gözler önüne sermektedir. Son olarak makale İslamcı feminist söylemin vadettiklerine ve sınırlılıklarına işaret etmektedir.

Anahtar Kelimeler: İslamcı Feminizm, İslamcı Feminist, İslamcı Kadın, Feminist Söylem, Kadın Yazını.

\section{Giriş}

Feminist eleştiri XIX. yüzyılda sistemli bir düşünce biçimini alırken ana eğiliminin liberal teoriye yakın ve taleplerinin reformcu olduğu görülmektedir. ${ }^{1}$ Zaman içinde toplumsal taleplerde radikal yaklaşımlar gelişmiş ve feminist söylem her iki eğilimi içinde barındıra gelmiştir. Bu söylem kısa bir sürede liberal, radikal, varoluşçu, Marksist, sosyalist, siyahi gibi farklı yaklaşımlara ayrılmıştır, ancak batı-dışı toplumlarda gelişen feminist eğilimler daha genel tanımlamalara mahkûm edilmiştir. Bilhassa Müslüman toplumlar söz konusu olduğunda belirginleşen bu tavrı İslamcı feminizm ya da Müslüman feminizm gibi kullanımlarda görmek mümkündür. İslamcı

1 Bu eğilim ve feminist teoriler hakkında daha fazla bilgi için bk. Josephine Donavan, Feminist Teori, çev.: Aksu Bora, Meltem Ağduk Gevrek, Fevziye Sayılan (Iletişim Yayınları: İstanbul, 2001). 
feminizm kavramı daha yaygın bir kullanım alanına sahiptir ve farklı Müslüman toplumlarda yaşayan kadınların tecrübeleri ile batı ülkelerinde yaşayan Müslüman entelektüel kadınların yaklaşımlarına işaret etmektedir. Dolayısı ile bu kavram hem kadın hareketlerine hem de entelektüel üretime atıf yapmaktadır.

Batıda gelişen feminist eğilimleri birbirinden ayıran ana unsur ilk başlarda reformcu ya da radikal değişim talepleri iken zamanla feminist eleştiri farklı siyasi yaklaşım ya da düşünce hareketlerine göre çeşitlenmiştir. Bu noktadan hareketle 1990'lı yıllarda kullanıma giren İslamcı feminizm kavramının İslamcı hareketle ilişkilendirildiği düşünülebilir. Bu kavram İngilizce literatürde yaygın bir şekilde Islamic feminism şeklinde kullanılmaktır. Yerine ideolojik bir yaklaşımı ya da siyasi hareketi vurgulayacak şekilde Islamist feminism kullanımının tercih edilmemiş olması dikkat çekmektedir. ${ }^{2} \mathrm{Oy}$ saki bu kullanıma yöneltilen ilk eleştiriler, aktivist olsun olmasın her kadının feminist olarak tanımlanmasının sorunlu olduğu ve İslamcı hareket içinde feminist eleştirinin barınamayacağ1 yönündedir. ${ }^{3}$ Moghissi, bu konudaki tereddüdünü "İslamcı feminizm, feminizmin mi yoksa İslamcılığın mı bir çeşididir?" şeklinde dile getirmektedir. ${ }^{4}$

Türkiye' de yapılan çalışmalarda İslamcı kadın hareketine referansla dindar kadınlar arasında gelişen feminist eğilim tartışılırken İslamcı feminizm kavramının yaygınlık kazanmaması dikkat çekicidir. ${ }^{5}$ Bu kavramın Türkçeye çevirisi hususunda da bir belirsizlik

2 Bu kavramın kullanıldığı çalışmalarda İslamcı hareket içinde yer alan kadın önderlere dair incelemeler yapıldığı görülmektedir. Örnek çalışmalar için bk. Pauline Lewis, "Zainab al-Ghazali: Pioneer of Islamist Feminism", Journal of History (2007): 1-47; Jeffry R. Halverson and Amy K. Way, "Islamist Feminism: Constructing Gender Identities in Postcolonial Muslim Societies", Politics and Religion 4/3 (2011): 503-525.

3 Sherine Hafez, An Islam of Her Own: Reconsidering Religion and Secularism in Women's Islamic Movements (New York and London: NYU Press, 2011), 7-8.

4 Haideh Moghissi, Feminism and Islamic fundamentalism: The limits of Postmodern Analysis (London and New York: Zed Books, 1999), 146.

5 Badran, 1990'lı yıllarda Türkiye' de İslamcı feminizm kavramının Yeşim Arat, Feride Acar ve Nilüfer Göle tarafından kullanıldığını söylemektedir. Bu, diğer Müslüman ülkelerdeki gelişmelere paralel tartışmaların Türkiye'de de yaşandığını varsayan Badran'ın yorumudur. Bk. Margot Badran, Feminism in Islam: Secular and Religious Convergences (Oxford: Oneworld Publications, 2013), 243. Göle eserinde bu kavramı kullanmamış, bir grup kadın yazar ve Ali Bulaç arasında yaşa- 
hâkim olagelmiştir. İslami ya da İslamcı feminizm şeklindeki çevirileri kullanan çalışmalar dikkatle incelendiğinde İslamcı harekete atfın zayıf olduğu görülmektedir. Bu da söz konusu söylemin reformcu bir yaklaşım olarak değerlendirildiğine ve kadın hareketinden bağımsız, daha kapsayıcı bir kullanım olarak algılandığına işaret etmektedir.

İslamcı feminizm kavramının neye işaret ettiğine dair belirsizlik, kavramın tatmin edici bir tanımının yapılamaması ile daha da girift bir hal almıştır. Bu kavramın kullanıma girmesinde oldukça etkili olan Margot Badran, Müslüman ülkelerde ortaya çıkan kadınduyarlı yaklaşımları ya da Müslüman kültürel kimliğine sahip kadınların çalışmalarını değerlendirirken oldukça geniş bir tanımlama denemesi yapmıştır. ${ }^{6} \mathrm{Bu}$ tanımlamaya göre Müslüman toplumlarda, içeriden bir bakışla, kadının konumunu ve haklarını tartışan herkes İslamcı feminist söylemin oluşumuna katkı yapmaktadır. Bu yaklaşım beraberinde pek çok tartışmayı getirmiş, İslamcı feminizm başlığı altında değerlendirilen kadın yazını ile bu görüşlerin benimsenmesi arasında bir ayrım gözetilmemesine yol açmıştır. Kavram yaygınlık kazandığı andan itibaren İslam ve feminizm kavramlarınin yan yana gelip gelemeyeceği ve bu kavramın bir oxymoron olup

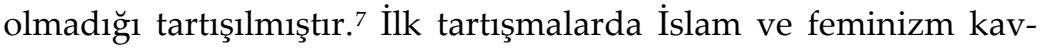
ramlarının birlikte kullanılamayacağı yönündeki görüşün baskın olduğu görülmektedir. Kavramın kullanımı başlarda hoşnutsuzluk meydana getirmiş ise de zaman içinde Müslüman kadınlar arasında gelişen eleştirel bakışa işaret ettiği için kabul görmüştür. Feminist eleştiriden istifade eden ancak kendilerini feminist olarak tanımla-

nan tartışmalara işaret etmiştir. Bk. Nilüfer Göle, The Forbidden Modern: Civilization and Veiling (Michigan: University of Michigan Press, 1996), 122-127. Benzer şekilde Arat da Türkiye ile ilgili değerlendirmelerinde İslamcı feminizm kavramını kullanmamaktadır. Bk. Yeşim Arat, "Islamist Women and Feminist Concerns in Contemporary Turkey: Prospects for Women's Rights and Solidarity", Frontiers: A Journal of Women Studies 37/3 (2016): 125-150.

6 Badran'ın yaklaşımı için bk. Margot Badran, Feminism in Islam, 242-259, 279-296.

7 Bu konudaki tartışmalar için bk. Deniz Kandiyoti, "Contemporary Feminist Scholarship and Middle East Studies", in Gendering the Middle East: Gender, Culture and Politics in the Middle East, ed.: L. Ahmed, M. Cook and S. Sharoni (Syracuse, NY: Syracuse University Press, 1996), 1-28; Moghissi, Feminism and Islamic Fundamentalism, 126-127, 134; Miriam Cooke, Women Claim Islam: Creating Islamic Feminism through Literature (New York and London: Routledge, 2004), 59; Raja Rhouni, Secular and Islamic Feminist Critiques in the Work of Fatima Mernissi, vol. 9 (Leiden and Boston: Brill, 2010), 27-31. 
mayan pek çok düşünür, kadın konusunda yazdığı ya da görüş bildirdiği için İslamo feminist olarak kabul edilmiştir. Bu yaklaşıma paralel olarak farklı ülkelerden Müslüman kadın düşünürlerin toplumsal cinsiyet, ataerkillik, aile, kadın hakları ile ilgili çalışmaları $\dot{I}_{S}$ lamoı feminizm başlı̆̆ı altında değerlendirilmiştir. Bu kullanımların uygunluğu konusundaki hoşnutsuzluklar devam etmekle birlikte bu tartışmalar, Müslüman kadın bilinçliliği ya da eleştirelliğinin düşünce hayatındaki yansımalarını ifşa ettiği için incelenmeye değerdir. ${ }^{8}$

Bu tartışmalarda dikkate alınması gereken ilk nokta İslamcı feminist söyleme katkı yaptığı düşünülen çalışmaların geniş bir yelpazeye yayılmasıdır. Müslüman toplumlarda kadın konusunu ele alan, İslami kaynaklarda kadınla ilgili yaklaşımları değerlendiren hemen her çalışma, şayet yazarı da Müslüman -kültürel ya da dini anlamda- kimliğine sahip ise bu söyleme katkı yaptığı kabul edilmektedir. ${ }^{9}$ Müslüman ülkelerdeki kadın hareketlerini de içine alan İslamcı feminist söylem, Tohidi'nin ifade ettiği gibi hem ataerkillikle hem de modern ve post-modern durumlarla yüzleşmenin ve onlarla mücadelenin bir ifadesi olarak görülmektedir. ${ }^{10}$ Bununla birlikte bu söylem ile ilgili çalışmalarda Müslüman kadınların görüş ayrılıkları, din ve gelenek içinde kadının konumuna dair yorumlarındaki farklılıklar dikkate alınmamaktadır. Aksine çalışmalarda çoğu zaman bu kadın düşünürlerin yaklaşımlarında tek bir izlek varmış gibi hareket edilmektedir. Bu husus bilhassa dini hassasiyetleri olan kadın düşünürlerin çalışmaları değerlendirilirken ortaya çıkmaktadır. Hâlbuki her bir Müslüman ülkeye göre değişen ve o ülkenin özgül

8 Ayşe Güç, “İslamcı Feminizm: Müslüman Kadınların Birey Olma Çabaları”, Uludă̆ Üniversitesi İlahiyat Fakültesi Dergisi 17/2 (2008): 654.

9 Bu tutum İslamcı feminizmin tanımlanmasında etkin bir isim olan Margot Badran'1n yaklaşımlarında net bir şekilde görülmektedir. Bk. Margot Badran, “Understanding Islam, Islamism, and Islamic Feminism", Journal of Women's History 13/1 (2001): 47-52; Margot Badran, "Islamic Feminism: What's in a Name?", AlAhram Weekly Online 569 (2002): 17-23.

10 Nayereh Tohidi, "Islamic Feminism: Perils and Promises", Middle Eastern Women on the Move (Woodrow Wilson International Center for Scholars, Washington, 2003), 135-146. 
koşullarına göre ön plana çıkan tartışmalar ya da kadın hareketleri mevcuttur. ${ }^{11}$

İslamcı feminizm kavramı ile işaret edilmek istenen kadın yazınları ve hareketleri değerlendirilirken Müslüman kadın kategorisi seküler ve dindar kadınlar arasında bir ayrımı gözetmeksizin kullanilmaktadir. Bu niteleme her ne kadar analitik bir zorunluluktan kaynaklanıyor olsa da yönelimlerdeki farklılıkları görmeyi engellemektedir. Bu genelleştirici yaklaşım batı-dışı toplumlar söz konusu olduğunda belirgin hale gelmektedir. Dini aidiyeti sadece kültürel bir kimlik kabul ederek kadın yaşamındaki değişimi ya da batı-dışı toplumlardaki kadınların üretimlerini değerlendirmek yanıltıcı olacaktır. İslamcı feminist söylem söz konusu olduğunda bu tarz bir değerlendirme dünya görüşleri arasında farklılık olan kadın yazarların batılı feminist söylem karşısındaki konum alışlarını incelemeyi güçleştirmektedir. Bu sebeple bu söylem incelenirken düşünsel alanda belirginleşen temsil sorunu zihinde tutulmalıdır ve şu sorular sorulmalıdır; "Müslüman kadın” kimdir? Müslüman kadın kim tarafından temsil edilmektedir? İslamcı feminizm ve feminist kavramlaştırmaları kimler tarafından önerilmiştir? Bu sorular önemlidir. Zira XIX. yüzyılda İslam kültürü içinde yetişen erkek düşünürler bir taraftan Müslüman kadının haklarını savunurken öte yandan oryantalist, sömürgeci, feminist söylemler Müslüman kadının temsil hakkına katkı yaptıklarını iddia etmişlerdir. Bu çatışma alanı hiç şüphesiz ki yeni bir temsil sorunu doğurmuştur. Bu temsil sorunu, makalenin odak noktası İslamcı feminist söylem olduğu için daha da önem kazanmaktadır. Bu söylemin sınırlılıklarını ve potansiyelini ortaya koyabilmek için önce kavramların kullanımında bir mutabakata varılması gerekmektedir. Belirtilen bu husus kadın çalışmalarındaki baskın yaklaşım farklı görüşten kadın düşünürleri "Müslüman kadın" kategorisi içine hapsetme eğiliminde olduğu için daha da önemlidir. İslamcı feminizm başlığı altına toplanan çalışmaların pek çoğunda dini inanç ve pratikler karşısında farklı duruş noktalarına sahip inançlı ve seküler kadınlar arasında bir ayrıma gidilmemektedir. Bu ayrım dikkate alınmadığı için kadın yazınları arasındaki yaklaşım farkları da görmezden gelinmiş olmaktadır. Bu

11 Bu makalede İslamcı feminist söylemi ürettiği düşülen çalışmaların tamamı için Müslüman kadın yazını tanımlaması kullanılmaktadır. Bu kadın yazını içindeki temel iki eğilim ise İslamcı kadın yazını ve seküler Müslüman kadın yazını olarak belirtilmektedir. 
tutum kadın düşünürleri tanımlarken de ortaya çıkmakta, dini metinlerde kadın algısı üzerine yazan, içinde yaşadığı toplumdaki konumunu ve haklarını tartışan kadın yazarlar İslamcı feminist kabul edilmektedir. Bu baskın tutum İslamcı feminist söylemi bütünlüklü bir şekilde incelemeyi de güçleştirmektedir. Bu sebeple makale farklı yaklaşımları "Müslüman kadın yazını" başlığı altında toplamakta ve bu yazında iki ana eğilimin olduğuna işaret etmektedir. $\mathrm{Bu}$ eğilimlerin incelenmesi ile İslamcı feminist söylem başlığı altında toplanan görüşler daha iyi anlaşılabilecek ve bilhassa İslamcı feminist kullanımının kadın yazınlarındaki çeşitliliği nasıl gölgelediği ortaya konmuş olacaktır.

Müslüman kadın ile ilgili içeriden bir bakışla yapılan çalışmaları değerlendirebilmek için din ve geleneğe karşı tutumları farklılaşan seküler Müslüman kadınlar ile İslami bir hayat görüşüne sahip kadınlar arasında ayrım yapmak önemlidir. Bu nedenle makalede ikinci grup, ideolojik bir yönelimi kastetmeksizin ve analitik kolaylık sağlayacağı için İslamcı kadın olarak nitelendirilmiştir. ${ }^{12}$ Buna göre Fatıma Mernissi, Nevval Saadawi, Fetna Ayt Sabbah gibi düşünürlerin görüş ve yaklaşımları seküler Müslüman kadın yazını içinde13; Amina Wadud, Aziza Hibri, Asma Barlas, Rifat Hassan, Kecia Ali, Hidayet Şefkatli Tuksal, Cihan Aktaş gibi düşünürlerin görüş ve yaklaşımları ise İslamcı kadın yazını ${ }^{14}$ içinde değerlendirilmiştir. İslamcı feminist söyleme katkı yaptığı düşünülen bu kadın

12 Makalede İslamcı kadın ifadesi, Islamic feminism kullanımı dikkate alınarak ve anlam karmaşası meydana getirme riski baştan kabul edilerek kullanılmaktadır. Makalenin öncelikli amacı batılı feminist söylemin baskın tavrına işaret etmek olduğu için bu kullanımdaki sorunlar şimdilik göz ardı edilmektedir. İslamcı kadın yazını içinde de farklı yaklaşımlar bulunabilir, ancak bu husus makalenin kapsamı dışında kalmaktadır.

13 Bk. Fatıma Mernissi, The Veil and The Male Elite: A Feminist Interpretation of Women's Rights in Islam, trans.: Mary Jo Lakeland (USA: Addison-Wesley Publishing Company, 1991); Fatıma Mernissi, Peçenin Ötesi, çev.: Mine Küpçü (İstanbul: Yayınevi Yayıncılık, 1995); Kadınların İsyanı ve İslami Hafıza, çev.: Aytül Kantarcı (Ankara: Epos Yayınları, 2003); Nevval Saadawi, Havva'nın Örtülü Yüzü, çev.: Sibel Özbudun (İstanbul: Anahtar Kitaplar, 1991); Fetna A Sabbah, İslam'ın Bilinçaltında Kadın, çev.: Ayşegül Sönmezay (İstanbul: Ayrıntı Yayınları, 1995).

14 Bk. Amina Wadud, Quran and Woman: Rereading the Sacred Text from a Woman's Perspective (New York: Oxford University Press, 1999; Inside the Gender Jihad: Women's Reform in Islam (London: Oneworld Publication, 2008); Azizah Y. Hibri, Women and Islam (Oxford and New York: Pergamon Press, 1982); "A Study of Islamic Herstory: Or How Did We Ever Get into This Mess?", Women's Studies 
yazınları arasındaki ayrışma noktalarını görmek önemlidir. ${ }^{15} \mathrm{Bu}$ nunla birlikte her iki kadın yazınını birleştiren en temel noktanın din ve gelenek içinde kadının konumunu tartışmaya açmaları olduğu söylenebilir.

Bu kadın yazınları değerlendirilirken karşılaşılan ilk belirgin sorun İslamcı feminist ifadesinin kullanımında ve bir kimlik olarak sahiplenilmesinde ortaya çıkmaktadır. Pek çok Müslüman kadın düşünür açıkça İslamcı feminist olmadığını ifade etmiş, yine de bu tanımlamadan kurtulamamıştır. ${ }^{16}$ Nazife Şişman, kendisinin neden feminist olmadığını Miriam Cooke'a anlatmakta güçlük çektiğini şöyle ifade etmektedir: "Zira bir taraftan kadınların kamusal alanda yer almasını olumlu karşılıyordum. Diğer taraftan içtihadın İslami ilim geleneği içindeki yerine istinaden, pek çok konuda olduğu gibi kadınlarla ilgili konularda da yeni düzenlemeler yapılabileceğini söylüyordum. Peki neden feminist değildim?" Aynı şekilde net bir şekilde itiraz etmesine rağmen İslamcı feminist olarak anılan Asma Barlas, kendisini "inanan" olarak tanımlamayı tercih ettiği halde batılı feminizmin üstenci tavrını karşısında nasıl çelişkili ve çatışmalı

International Forum 5/1 (1982): 212-215; "Deconstructing Patriarchal Jurisprudence in Islamic Law: A Faithful Approach", in Global Critical Race Feminism: An International Reader, ed.: Adrien Katherine Wing (New York: New York University Press, 2000); Asma Barlas, Believing Women in Islam: Unreading Patriarchal Interpretations of The Qur'an (Austin: University of Texas Press, 2002); Rifat Hssan, "Equal Before Allah? Woman-man Equality in the Islamic Tradition", Harvard Divinity Bulletin 17/2 (1987): 2-14; “Feminist Theology: The Challenges for Muslim Women", Critique: Journal for Critical Studies of the Middle East 5/9 (1996): 5365; "Feminism in Islam", Feminism and World Religions, eds.: Arvind Sharma ve Katherine K. Youngs (Albany: State University of New York Press, 1999), 248279; Kecia Ali, Sexual Ethics and Islam: Feminist Reflections on Qur'an, Hadith and Jurisprudence (Oxford: Oneworld Publications, 2015); Hidayet Ş. Tuksal, Kadın Karşıtı Söylemin İslam Geleneğindeki İzdüşümleri (Ankara: Kitabiyat, 2001); Cihan Aktaş, Sistem İçinde Kadın (İstanbul: Beyan Yayınları, 1988); Mahremiyetin Tükenişi (İstanbul: Nehir Yayınları, 1995).

15 Ayşe Güç, “Feminist Söylemin İslamcı Kadın Yazarlar Üzerindeki Etkisi” (Bursa: Uludağ Üniversitesi, Sosyal Bilimler Enstitüsü, Yüksek Lisans Tezi, 2007); Ayşe Güç, “Feminist Söylemin İslamcı Kadın Yazınına Etkisi”, Kadın/Woman 2000 19/2 (2018): 52-71.

16 Nazife Şişman, Global Konferanslarda Kadın Politikaları (İstanbul: İz Yayıncılık, 1996), 81. Bu noktaya işaret eden Moghissi' ye göre bu tanımlamayı genellikle diasporadaki Müslüman kadınlar benimsemiş, Müslüman ülkelerde yaşayan kadınlar mesafeli kalmıştır. Bk. Moghissi, Feminism and Islamic Fundamentalisms, 126. 

durumların içine girdiğini aktarmaktadır. ${ }^{17}$ Amina Wadud da başta feminist nitelemesine mesafeli olmasına ve zaman içinde kendini pro-feminist olarak tanımlamasına rağmen İslamcı feminist olarak tanımlanmıştır. ${ }^{18}$ Bu kullanım açıkça kadın çalışmalarındaki hâkim tavra işaret etmektedir. Yine de İslam kültürü içinde gelişen ve özgün üretimleri olan bir kadın söyleminin varlığının kısmi kabulü anlamına geldiği için göz ardı edilmemelidir. Bu kavramsal kullanımların yarattığı sorunlara işaret ettikten sonra İslamcı feminist söylemin ortaya çıkış sürecini ele almak, seküler Müslüman kadın yazını ile İslamcı kadın yazını arasındaki benzerlik ve farkları ana hatları ile işaret etmek yerinde olacaktır.

\section{İslamcı Feminist Söylemin Ortaya Çıkış Süreci}

Müslüman kadın düşünürler, din ve gelenek içinde kadınla ilgili konuları eleştirel bir bakış açısı ile değerlendiren, toplumsal cinsiyet eşitliğini vurgulayan, geleneğin ve dini yorumların ataerkil karakterini sorgulayan, başta Kur'an-1 Kerim olmak üzere dini metinlerde kadın-erkek ilişkilerine dair ifadeleri ve İslam tarihinde kadının durumunu inceleyen çalışmalar üretmişlerdir. Bu çalışmalar, 1990'11 yıllarda belirgin hale gelen yeni bir sürecin düşünce hayatındaki yansımaları olarak değerlendirilebilir. İslamcı feminist söylem, Müslüman kadın düşünürlerin kadının toplumsal konumu, kadınlık kimliği ve kadınlık rolleri hakkında savunmacı bir noktadan çıkıp eleştirel bir tutum içinde özgün eserler üretebildikleri bir sürece işaret etmektedir.

Bu söylemin ortaya çıkışında, Müslüman kadını bir kategori olarak sorunsallaştıran oryantalist ve sömürgeci söylemlerin önemli bir etkisi olmuştur. Denilebilir ki paradoksal bir biçimde İslam kültürü içinde gelişen eleştirel kadın bilinçliliğini ilk tetikleyenler batılı sömürgeci ve oryantalist erkekler olmuştur. Sömürgeci erkekler, toplumsal değişimde kadının özel bir yeri olduğuna inanmışlar ve kadın yaşamının çözülmesi ile Müslüman toplumların batı karşısında güçsüzleşeceğine inanmışlardır. Bu sebeple Müslüman kad1nın topluma katılımı ve ataerkil sistemlerden özgürleştirilmesi konularına özel bir önem vermişlerdir. Cezayir örneğinde sömürgeci

17 Bk. Asma Barlas, "Engaging Islamic Feminism: Provincializing Feminism as a Master Narrative", Islamic Feminism: Current Perspectives, ed.: Anitta Kynsilehto (Tampere, Finland: University of Tampere, 2008), 15-23.

18 Amina Wadud, Inside the Gender Jihad: Women's Reform in Islam (London: Oneworld Publication, 2008), 4. 
erkekler, Fanon'un türban savaşı olarak tanımladığı bir girişimi teşvik etmişlerdir. Buna göre Cezayirli kadınların halk meydanında başlarını açmaları, sömürgeci erkekler tarafından ataerkil sisteme bir başkaldırı ve özgürleşme savaşı olarak desteklenmiştir. ${ }^{19}$ Diğer taraftan oryantalistler olumsuz bir İslam imajı inşa ederken kadın yaşamı ve özel alanla ilgili peçe, örtü, harem gibi konuların işlenmesine özel bir önem vermişlerdir. ${ }^{20}$ Bir öteki olarak Doğu'yu inşa etmeye çalışan bu söylemlerin Müslüman düşünürler üzerinde derin etkileri olmuştur. Bu söylemlerde işlenen Müslüman kadının toplumda geri kalmış olduğu fikri, kadınların eğitim hakkı olmak üzere temel haklardan mahrum bırakılmaları ile ispatlanmaya çalışılmıştır. Bu fikri desteklemek için batılı erkekler, Leila Ahmed'in de işaret ettiği gibi, kendi toplumlarındaki feminist hareketlere karşı çıkarlarken, liberal feminist eleştiriyi İslam ülkeleri özelinde dile getirmekten çekinmemişlerdir. ${ }^{21}$ Lord Cromer gibi sömürgeciler, kendi ülkelerinde tam tersi bir tavır sergilemiş ve Müslüman kadının eğitim hakkı için özel gayret göstermişlerdir. ${ }^{22}$ Sömürgeci ve oryantalist söylemlerin Müslüman erkek düşünürlerde -ve tartışmalara katılabilen kadınlarda- savunmacı bir yaklaşımı doğurduğu söylenebilir. Bu savunmacı yaklaşımı İslam'da Kadın başlığı ile yapılan çalışmalarda görmek mümkündür. Genel itibari ile bu çalışmaların temel tezi, İslam dininin kadına haklar verdiği, geleneksel yaklaşımların ve toplumsal adetlerin bu hakların uygulanmasını engellediği şeklindedir. Müslüman toplumlara dışarıdan gelen etkilere karşı üretilmiş bu türden çalışmalar aynı zamanda batı-dışı toplumlarda yaşanan fikri plandaki travmaları inceleme imkânı da sunmaktadır.

Müslüman kadının temsili ile ilgili tartışmalarda bir diğer odak noktası feminist yaklaşımlardır. XIX. yüzyılda batılı feminist söylem sistemleşirken bir yandan da oryantalist ve sömürgeci erkekler vasıtasıyla batı-dışı toplumları özellikle de İslam kültür coğrafyasını etkileyebilmiştir. Bu süreç batılı feminist söylemin bir meta-anlatı olma yolundaki tavrını da desteklemiş görünmektedir. Milliyetçi hareketlerde ve uluslaşma sürecinde etkili olan aydınlar vasıtasıyla

19 Zehra Ali (der.), İslamî Feminizmler, çev.: Öykü Elitez (İstanbul: İletişim Yayınları, 2008), 193-194.

20 Saddeka Arebi, "Gender Anthropology in the Middle East", The American Journal of Islamic Social Sciences 2/8 (1991): 99-100.

21 Leila Ahmed, Women and Gender in Islam: Historical Roots of a Modern Debate (New Haven, London: Yale University Press, 1992), 243.

22 Ahmed, Women and Gender, 243. 
kadın bedeni toplumsal değişimin en önemli sembollerinden birine dönüşmüş, kadının kamusal hayattaki temsili toplumsal ilerlemenin bir göstergesi olarak kabul edilmiştir. Böylece oryantalist ve sömürgeci söylemlerle tetiklenen Müslüman kadının kamusal görünürlüğ̈̈ ve hakları meselesi günümüze kadar devam eden bir tartışmaya dönüşmüştür. Bu tartışmalara batılı feminist söylemin argümanları da eklenince Müslüman kadın düşünürlerin kendi toplumlarında milliyetçi-ulusalcı erkeklere karşı belli oranda direnç gösterebildikleri, öte yandan feminist, sömürgeci ve oryantalist görüşlere karşı savunmacı bir üslup benimsedikleri bir süreç yaşanmıştır. Bu hususu Osmanlı kadın hareketi ile Mısır'daki kadın hareketleri örneklerinde görmek mümkündür.

Müslüman kadının temsil sorunu ile ilgili işaret edilmesi gereken bir diğer önemli nokta ise Batılı kadının sembolik-hiyerarşik sunumudur. Batılı feministler kendilerini Doğulu kadının karşısına yerleştirerek özgür tahayyül etmektedirler. Hatem'e göre bu tahayyül onlara kendi durumlarının gerçekliği ile yüzleşmekten, dolayısı ile önemli bir çatışmadan kaçma imkanı vermektedir. ${ }^{23}$ Yeğenoğlu'nun emperyal feminist ${ }^{24}$ olarak tanımladığı bu batılı feministler, bir öteki olarak Doğu'nun kurgusuna ya da erkek karşısında kadının ötekileştirilme sürecine benzer ve kendi geleneklerindeki dikotomik hiyerarşik yapıları olumlayan bir kurgunun içinde hapsolmuş, özgür batılı kadının karşısında batı-dışı toplumlarda yaşayan kadınları yerleştirerek ezilmenin yeni bir çelişkisini inşa etmiştir. Batılı feminist söylem, Müslüman toplumlara dair oryantalist ve sömürgeci eril tavrın olumlanması anlamına da gelen, peçelerinden ve örtülerinden kurtarılması, özel alandan özgürleştirilmesi gereken kadınlara karşı hiyerarşik bir konum almıştır. Bu konum alışın postkolonyal incelemelerle yapı-bozumuna uğratıldığı, ancak kavramsal kullanımlardaki dayatma ile halen etkisini devam ettirdiği söylenebilir. Bilhassa Müslüman kadın söz konusu olduğunda belirginleşen bu tavrın yok olmadığı, sadece form değiştirdiği İslamcı feminizm/feminist kavramlarının kullanımında net bir şekilde görülmektedir.

23 Mervat Hatem, “Through Each Other's Eyes: Egyptian, Levantine-Egyptian, and European Women's Images of Themselves and of Each Other (18621920)", Women's Studies International Forum 12/2 (1989): 183-198.

24 Medya Yeğenoğlu, Sömürgeci Fantaziler: Oryantalist Söylemde Kültürel ve Cinsel Fark (İstanbul: Metis Yayınları, 2003), 130. 
Müslüman kadının temsili konusunda oryantalist ve sömürgeci söylemlere karşı milliyetçi muhalefetin bazı önemli sonuçları olsa da batılı feminist söylemden gelen etkiler bu muhalefetin çelişkili bir şekilde kırılmaya uğradığını göstermektedir. Bu çatışma alanı her şeyden önce özgürlük durumunu sorgulayan Müslüman kadınları daha da edilgen kılmıştır. Milliyetçi hareketler ve uluslaşma süreçleri ile 1980'li yıllar arasındaki dönemde Müslüman kadın özne, toplumsal görünürlüğü ve toplumsal yaşama katılımı konusundaki bu çekişme alanında gittikçe silikleşmiş gibidir. Bu dönemde Müslüman kadının konumu, Spivak'ın ifadesi ile "çifte bir gölgede" bırakılmıştır. ${ }^{25}$ 1980'ler sonrasındaki süreçte Müslüman kadın düşünürler, kendi adlarına konuşma hakkını geri kazanmak için hem bu çatışma alanını hem de bu alanın inşasına katkıda bulunan tarafları sorgulamak zorunda kalmışlardır.

Müslüman kadının toplumsal konumu ve haklarının savunmacı bir tarzda ele alınmasında milliyetçi hareketlerin ve uluslaşma çabalarının etkisi olmuştur ve bu etki halen devam etmektedir. Bu sürece, sömürgeci ve oryantalist söylemler ile başlatılan tartışmaların İslam ülkelerinin modernleşme/batılılaşma yanlısı aydınları tarafından benimsenmesi ile kaçınılmaz bir şekilde girilmiştir. Bununla birlikte, 1980'lerden itibaren Müslüman kadınların daha eleştirel bir tutum takınması ile yeni bir söylemin oluşmaya başladığı görülmektedir. ${ }^{26}$ İslamcı olarak nitelendirilen kadın hareketlerine düşünsel zemini hazırlayan ancak onlardan bağımsız olan bu entelektüel çabaları, özellikle teoloji, felsefe, sosyoloji, antropoloji ve kültür çalışmalarından beslenen düşünce çizgisini İslamcı feminist söylem olarak ele almak mümkündür. Bu eleştirel kadın bilinçliliğini teşvik eden itici gücün Müslüman kadının kendisini temsil hakkını geri kazanmak olduğu söylenebilir. Bu sebepledir ki çalışmalarda sadece dini kaynaklara değil sosyal bilimlerin üretimlerine de müracaat edilmektedir. Amina Wadud, Rifat Hassan, Aziza Hibri, Asma Barlas, Kecial Ali, Hidayet Şefkatli Tuksal gibi kadın düşünürlerin çalışmaları ile İran'da bir dönem çıkartılmış olan Zanan

25 Gayatri C. Spivak, "Can the Subaltern Speak", Marxism and the Interpretation of Culture, der.: Cary Nelson ve Lawrence Grossberg (Urbana, Chicago: University of Illinois Press, 1988), 288.

26 Bu yıllardan hareketle İslamcı feminist söylemi İran örneği ile değerlendirmek ya da bu alana hapsetmek haksızlık olacaktır. Bu gelişmeyi, ulusların öznel tecrübelerinin ötesinde uluslararası arenada meydana gelen gelişmelerle ve batıdaki ikinci dalga feminist hareketlerle ilişkilendirmek daha makuldür. 
dergisi ${ }^{27}$, Malezya' da halen aktif olan Sisters in Islam (SIS)' $1 n^{28}$ yayın faaliyetleri incelendiğinde bu husus daha net görülecektir.

İslamcı feminist söylemin üretiminde İran, Mısır, Malezya gibi ülkelerdeki tartışma ve yayın faaliyetlerinin, yaygınlık kazanmasında ise Batı ülkelerinde yaşayan Müslüman kadın düşünürlerin katkısı önemli olmuştur. Bu söylemin kökleri, XIX. yüzyılda İslam ülkelerindeki batılılaşma/modernleşme çabalarına katılan kadın ve erkeklerin düşüncelerine kadar götürülebilir. Bu yüzyılda Türkiye (Osmanlı) ${ }^{29}$, Mısır ve İran' da ortaya çıkan kadın hareketleri, eleştirel kadın bakış açısının ürünü oldukları için İslam kültürü içinde gelişen bir kadın bilinçliliğinin varlığına işaret etmektedir. Bu bilincin gelişiminde, kadın haklarının tanınmasından ziyade savunusuna odaklanmış olan erkek düşünürlerin önemli etkisi olmuştur. Bu düşünürlerden Kasım Emin'in Tahrir'ül Mer'e ve Halil Hamit'in Islamiyette Feminizm yahut Alem-i Nisvanda Müsavat-ı Tamme ${ }^{30}$ adlı kitapları bu etkiyi göstermesi bakımından kayda değerdir. Bu görüşlerden beslenen kadın düşünürler zamanla eleştirel ve özgün bir söylem inşa etmişlerdir. Bu söylemin gelişimi uluslaşma süreçlerinde sekteye uğramış, tekrar canlanması için 1980'li yılların ulusal ve uluslararası gelişmelerini beklemek gerekmiştir. ${ }^{31} \mathrm{Bu}$ tarihlerden itibaren Müslüman kadınlar hem içinde bulundukları siyasi-sosyal yapıları sorgulamaya hem de gelenek ve dinlerinde kendilerini rahatsız eden meseleleri tartışmaya başlamışlardır. Müslüman kadın

27 Dini metinlerin yeninden yorumlanması hususunda etkili olan Zanan dergisi 2008 yılında kapatılmıştır. Kapatılması ile ilgili Margot Badran'ın yaptığı değerlendirme için bk. http://www.theamericanmuslim.org/tam.php/features/articles/iran_closing_of_zanan_equality_at_half_mast/0016121.

Bk. Serpil Çakır, Osmanlı Kadın Hareketi (İstanbul: Metis Yayınları, 1996).

30 Bk. Kasım Emin, Tahrir'ül Mer'e (Tunus: Darü'l-Maarif: 1990); Halil Hamit, $\dot{I}_{S-}$ lam'da Feminizm (İstanbul: Okumuş Adam Yayınları, 2001).

31 1960'ların radikal hareketleri feminist eleştiride de yankı bulmuştur. Siyahi kadın hareketi ya da radikal feminist yaklaşımlarda görüleceği üzere birinci dalgada yer alan kız kardeşlik söylemi tartışılmış, feminist teorilerin hangi kadını ele almakta olduğu bir sorunsal haline gelmiştir. Bu dönemde ikinci dalga feminizmin etkileri Türkiye'ye de yansımıştır. Sol hareket içinde yer alan kadın düşünürler Kemalist feminist anlayışa eleştirel bir tutum takınmışlar, yer aldıkları hareketlerdeki erkeklerin baskın tavırlarını sorgulamaya başlamışlardır. Bununla birlikte ikinci dalga feministlerin İslamcı hareket içinde yer aldığı düşünülen hemcinslerine karşı mesafeli tutumlarında bir değişim yaşanmamıştır. Aksine İslamcı olarak nitelendirilen kadınlar bu dönemde hem muhafazakâr hem de seküler çevrelere karşı kendilerini adına konuşma mücadelesi vermişlerdir. 
düşünürler, din ve gelenekle ilgili ortak kaygıları ifade ederken bir yanda da ülkelerine özgü sorunları tartışmışlardır. Bu husus, İslamcı feminist söylem altında birleştirilen yaklaşımların tek bir çizgide devam etmediğinin anlaşılabilmesi açısından önemlidir.

Badran'a göre Müslüman toplumlarındaki İslam ve feminizm, kadın ve İslamcı hareketler hakkındaki tartışmaya katılan kadın ve erkekler bu söylemi üretmektedir. ${ }^{32}$ Bu yaklaşıma göre İslamcı feminist kimliğini kabul etmeyen yazarlar da yaptıkları çalışmalarla İslamcı feminizme katkı sağlamaktadır. ${ }^{33} \mathrm{Bu}$ değerlendirme BatılıDoğulu kadın ilişkisinin hiyerarşik doğasını ve Müslüman kadın kategorisinin indirgemeci yönünü ortaya koymaktadır. Hâlbuki Müslüman kadın düşünür gruplarının görüş ve yaklaşımlarında önemli farklar bulunmaktadır. İslamcı kadın yazarlar dini metinleri özellikle ana kaynağı söylemlerinin merkezine yerleştirip kadının toplumsal konumu ve hakları, toplumsal cinsiyet gibi konuları tartışmaya açarken kendilerini İslam dini ve geleneği içinde konumlandırmaktadırlar. Seküler Müslüman feministler ise dine karşı mesafeli durmakta, kimi zaman radikal görüşler dile getirmekte ve en önemlisi de eleştirilerini sadece geleneğe değil dine de yöneltmektedirler.

\section{Müslüman Kadın Yazını: Temel Yaklaşımlar, Benzerlikler ve Ay- rışmalar}

İslamcı feminizm başlığı altında değerlendirilen çalışmalar pek çok açıdan farklı dinamikleri içinde barındıran yeni bir kadın yazınına işaret etmektedir. Bu kadın yazını farklı yönelimleri olan iki kadın düşünür grubunun görüş ve yaklaşımlarını ihtiva etmektedir. Daha önce de değinildiği gibi İslamcı kadın düşünürlerin eleştirileri daha ziyade geleneği hedef alırken seküler Müslüman kadın düşünürler gelenek kadar dinin temel metinlerini de eleştiriye tâbi tutmuşlardır. İslamcı kadın düşünürlerin çalışmalarının merkezinde Kur'an'ın eşitlikçi yaklaşımı ve özellikle kullandığı tedrici metot yer almaktadır. Bu kadın düşünürler, ataerkillik ve toplumsal cinsiyet

32 Bk. Badran, "Understanding Islam, Islamism”. Kadınlık üzerindeki aşırı vurgu beraberinde erkekliğin sorgulanmasını ve toplumsal cinsiyet üzerinde yeni tartışmaları doğurmuş gibidir. Bu sebeple Müslüman kadınla ilgili tartışmalar daha dağınık bir hal almış ve erkek düşünürlerin bu tartışmalara etkisi giderek azalmiştır.

33 Bu yaklaşım, İslamcı feminizm kavramının sınırlarını belirsizleştirmekte ve gelişen bu yeni kadın yazının özgünlüğüne gölge düşürmektedir. 
konularına özel bir önem vermişlerdir. Onlara göre, Kur'an'da nazil olduğu toplumdan yansıyan kimi ataerkil yaklaşımlar olmakla birlikte kadının toplumda geri kalışının asıl sorumlusu gelenektir. Seküler Müslüman düşünürlere göre ise gelenek kadar dinin temel metinleri de ataerkil bir dile sahiptir ve bu dil kadını ontolojik olarak ikincil bir konuma hapsetmektedir. Her iki kadın düşünür grubunun geleneğin ataerkil karakteri ve asr-1 saadetin eşitlikçi yapısının zamanla değiştirilmiş olması noktalarında birleştikleri görülmektedir. Benzer şekilde Müslüman kadın düşünürlerin vahyin geldiği toplumda yaptığı düzenlemelerin ve Tanrı-insan, insan-insan, kadın-erkek ilişkisinde başlattığı değişimin neden kadınlar lehine gelişmeye devam etmediğini sorgulamada ortak bir noktada buluştukları söylenebilir. Bu kesişim noktaları, farklı eğilimdeki bu kadın düşünürlerin çalışmalarını Müslüman kadın yazını başlığı altında değerlendirmeyi mümkün kılmaktadır.

İslamcı kadın yazınında İslam dininin ana kaynaklarına müracaat edilmekte; Kur'an' daki ahlaki ilkelere vurgu yapılarak kadınlık ve erkeklik kategorileri yeniden incelenmekte, hadisler ve İslam hukuk metinlerindeki kadınlara karşı önyargılı yaklaşımlar tartışmaya açılmaktadır. Sorunlara farklı bir perspektiften çözüm arayan bu yazında itikadî konulardan ziyade muamelat (toplumsal) ile ilgili meseleler ele alınmakta ve Müslüman erkek yorumcuların tek yanlı bakış açıları tartışılmaktadır. Kadın düşünürler, toplumu ilgilendiren konularda Kur'an'ın tedrici düzeltme yönündeki tavrının neden çokeşlilik, kadınların şahitliği ve erkeklerin kadınlara kavvâm (hâkim/koruyup gözeten) olması gibi konularda uygulanmadığını sorgulamaktadırlar. Aynı zamanda tasavvufi söylemde olumlanan kadınsı özelliklerin ya da kadına verilen değerin hâkim söyleme neden sirayet etmediği, hâkim söylemde kadın konusunun neden bir açmaza dönüştüğü üzerinde de durmaktadırlar. Ana sorunun gelenekte baskın olan ataerkil bakış açısı ve yorumlar olduğu tespitini yapan İslamcı kadın düşünürler, kadınla ilgili konularda erkek yorumcuların negatif tavrını eleştirmekte ve kadınla ilgili dile getirilen olumlu yaklaşımların hâkim söylemlerin etkisi ile görünmez kılındiğını belirtmektedirler.

Seküler Müslüman kadın yazını geleneğin ataerkil karakterine yöneltilen eleştirilerde İslamcı kadın yazını ile birleşmekte, dini metinlerin ataerkil karakteri konusunda ise ayrışmaktadır. İslamcı kadın yazınında Kur'an'da toplumsal cinsiyet eşitliğine imkân tanıyan 
ayetler ve ifadeler ön plana çıkartılırken seküler Müslüman kadın yazınında temel dini metinlerin eril bir dile sahip olduğu vurgulanmaktadır. Bu eril dil vasıtasıyla kadının erkek üzerinden temsil edildiği, dolayısı ile Tanrı karşısında silikleşen kadının ontolojik olarak erkeklerden aşağı bir kategoriye yerleştirildiği görüşü dile getirilmektedir. Bu yazında da asr-1 saadetin eşitlikçi yapısına vurgu yapılmakta, sonraki dönemlerde erkek düşünürlerin kadın-karşıtı bir yaklaşımı İslami ilimlere yerleştirdikleri ifade edilmektedir. Türkiye dışında üretilmiş çalışmalarda seküler Müslüman düşünürler, İslamcı kadın yazınında olduğu gibi, kavvâm ifadesini çözümlemekte, erkeklere aile içinde verilen bu sorumluluğun toplumun tüm alanlarına yaygınlaştırıldığını iddia etmektedirler. Onlara göre bu ifade ataerkilliğin dini metinlerle desteklendiğini gösteren en güçlü kanıtlardan biridir.

Her iki kadın yazını incelendiğinde İslamcı feminist söylemin belirgin yaklaşımının kadın bakış açısı ile İslami kaynakların yeniden gözden geçirilmesi ve yorumlanması olduğu söylenebilir. ${ }^{34}$ Moghadam'a göre İslamcı feministler Kur'an'1 yeniden yorumlayarak, şeriat hükümlerini yapıbozumuna uğratmışlardır. ${ }^{35}$ Tohidi'ye

Bu söyleme Türkiye' de yaşayan kadınların henüz yeterince katılmadığı söylenebilir. Türkiye' de İran, Mısır ve Malezya örneklerindekine benzer din ve gelenek içinde kadın konusunu, felsefi-teolojik bir düzlemde tartışan bir kadın grubunun olmaması dikkat çekicidir. Bu durum, Türkiye'deki kadın düşünürlerin, bu sahadaki entelektüel ilgilerinin henüz olgunlaşmadığını ve dolayısıyla henüz bu söyleme ciddi bir katkı yapmadıklarını göstermesi bakımından önemlidir. Badran gibi kimi düşünürler, Türkiye'de İslamcı hareket içindeki bazı kadınlar tarafından telaffuz edilen ve yeni gelişen bir feminizmin varlığına işaret etmişlerdir (Bk. Badran, "Understanding Islam, Islamism”). Ne var ki bu gelişmeyi İslamcı feminizm ya da organize olmuş bir kadın bilinçliliği olarak değerlendirmek oldukça güçtür. Türkiye' de yapılan çalışmaların İslamcı feminizm olarak değerlendirilen ve yeni gelişen kadın söylemindeki tartışmaları yönlendirecek düzeyde olmadığı görülmektedir. Müslüman kadın yazınındaki entelektüel çizgi, akademik çevrelerden de beslenen felsefi-teolojik değerlendirmeler ile sosyo-kültürel çözümlemeleri ihtiva etmektedir. Türkiye'de kadın düşünürlerin bu çizgiden uzağa düşmesinin nedeni, Osmanlı kadın hareketinde başlayan tartışmaların Cumhuriyet döneminde kesintiye uğraması ve Türkiye'deki kadın düşünürlerin büyük ölçüde ülke içi problemlere odaklanmaları olabilir. Özellikle başörtüsü yasağı konusunda harcanan çabalar, daha derin teolojik ve kültürel araştırmaların önünü kesmiş gibi görünmektedir.

35 Valentine M. Moghadam, "Islamic Feminism and Its Discontents: Toward a Resolution of the Debate", Signs: Journal of Women in Culture and Society 27/4 (2002): 1147. 
göre ise Kur'an'ın yeniden yorumunda içtihat söylemi ön plana çıkmıştır. ${ }^{36}$ Görüldüğü gibi İslamcı feminizm ile ilgili değerlendirmelerde Kur'an'in yeniden yorumlanması konusu gündeme gelmektedir. Seküler Müslüman feministler Kur'an'ın toplumdaki ataerkil yapıları meşrulaştırıcı yönüne vurgu yaparlarken İslamcı kadın yazarlar Kur'an'ın toplumsal cinsiyet eşitliğine imkân tanıdığı görüşünde israrcıdırlar. İkinci grubun Kur'an'ın eşitlikçi yaklaşımına vurgusunda İslam hukukunun ataerkil söylemden etkilenmiş olması ve hadislerin de ataerkil düşünce ve uygulamaları destekleyecek şekilde yorumlanabilir olması etkilidir. İslamcı feminist söylemin temel argümanı, Badran'a göre, Kur'an'da bütün insanların eşitliği prensibinin işlenmiş olmasıdır. ${ }^{37}$ İslamcı kadın yazarlar, Hucurât Sûresi 13. ayette belirtilen bu eşitlik prensibinin ataerkil düşünce ve uygulamalarla engellendiğini ve bu sebeple kadın-duyarlı bir bakış açısıyla Kur'an'ın yeniden yorumlanması gerektiğini savunmaktadırlar. Örneğin, Malezya' da faaliyet gösteren Sisters in Islam (SIS) grubu feminist terminolojiyi kullanarak tefsir çalışmaları yapmaktadır. Yine Wadud ve Barlas Kur'an'ın toplumsal cinsiyet eşitlikçi yaklaşımını ve kadının ontolojik konumunu incelemişlerdir. ${ }^{38}$ Kadın bakış açısı ile Kur'an okumalarına örnek olan bu tür çalışmalar, erkek yorumcuların tecrübelerine ve erkek merkezli sorunlara dayanan, dönemlerinin ataerkil bakış açısını barındıran klasik ve klasik sonrası tefsir yorumlarını sorgulamayı teklif etmektedir. Müslüman kadın yazınında sadece dini metinlerin çözümlenmesi ile sınırlı kalınmamıs, kadının toplumsal konumu ve hakları, toplumsal cinsiyet, kadına karşı şiddet gibi konular da ele alınmıştır. Kur'an ve hadisleri yeniden gözden geçiren pek çok kadın düşünür, kadınlara karşı şiddetin İslam dışı bir uygulama olduğu fikrinde birleşmiştir. ${ }^{39}$

İslamcı kadın yazarlar bilhassa Kur'an'da yer alan ve toplumsal cinsiyet eşitliğini tartışmayı mümkün kılan ifadeleri incelemektedirler. Onlara göre Kur'an'ın toplumsal cinsiyet eşitlikçi yaklaşımı yay-

\footnotetext{
36 Tohidi, "Islamic Feminism".

Badran, "Islamic Feminism".

38 Wadud, Quran and Woman; Wadud, Inside the Gender Jihad; Barlas, Believing Women in Islam.

39 Badran, "Islamic Feminism".
} 
gın ataerkil kültürlerin etkisini yansıtan tefsir külliyatlarında görünürlügünü yitirmiştir. ${ }^{40} \mathrm{Bu}$ sebeple, toplumsal cinsiyet konusu kadın-erkek eşitliğini vurgulayan ayetler bağlamında yeniden ele alınmalıdır. İslamcı kadın yazarlara göre kadın ve erkek arasında ontolojik açıdan bir fark yoktur. Bu görüşlerini Nisa Sûresi 1. ayette yer alan "sizi bir tek canlıdan yaratan, ondan eşini var eden ve her ikisinden pek çok kadın ve erkek meydana getiren..." ifadesi ile Hucurât sûresi 13. ayetteki "biz sizi bir erkek ve bir kadından yarattık..." ifadesine dayandırmaktadırlar. Aynı zamanda İslami prensipler ışığında erkeklik ve kadınlık kimliklerinin nasıl anlaşılması gerektiğini tartışan bu yazarlar, erkeklerin kadınlar üzerinde haksız güç kullanımına karşı uyarı ve öğütler içeren pek çok ayete işaret etmektedir. ${ }^{41}$ Toplumsal cinsiyete atıf yapan ayetlerin geleneksel yorumlarının hiyerarşik ilişkiler tesis ettiğini ifade eden Müslüman kadın düşünürler bu ayetleri kadın ve erkeğin kamusal alana eşit katılımı ve siyasi-sosyal eşitliği kapsayan daha belirleyici ayetler ış1ğında değerlendirmeyi teklif etmektedir. Toplumsal cinsiyet ile ilgili tartışmaların tamamında Nisa sûresi 34. ayette yer alan kavvâm (hâkim/koruyup gözeten) ifadesi ele alınmaktadır. Bu ifadenin, ataerkil bakışı yansıtır şekilde erkeklerin kadınlardan üstün olduğu şeklinde yorumlanmasına itiraz edilmektedir. ${ }^{42}$ Kadın düşünürlere göre, geleneksel yorumlarda erkek ve kadın arasında İslam'ın öngördüğü dini eşitlik inkâr edilmemiş ancak bu prensipler siyasi-sosyal eşitlik ruhunun gelişmesi için de kullanılmamıştır. ${ }^{43}$ Bu nedenle Kur'an'ı kadın-duyarlı bir bakış açısı ile yeniden okuyarak aile ve toplumda bu eşitliği yaymak gerekmektedir. Görüldüğü gibi İslamcı feminist söylemin en belirgin özelliği dini metinlerin kadın perspektifinden yeniden okunmasina yaptı̆̆ 1 vurgudur. Kur'an üzerinde çalışan kadın yazarlar arasında Amina Wadud, Rifat Hassan, Fatima Naseef, Aziza Hibri, Shaheen Sardar Ali gibi isimler yer alırken yine Rifat Hassan, Kecia Ali, Hidayet Tuksal gibi yazarlar da hadislerin kadın-duyarlı okumasını yapmayı denemişlerdir. Benzer

40 Badran, "Islamic Feminism".

41 Omaima Abou-Bakr, "Islamic feminism? What's in a Name? Preliminary Reflections", Middle East Women's Studies Review 15/4 (2001): 1-4.

42 Bu konudaki değerlendirmeler için bk. Y. Haddad ve John L. Esposito, eds.: Islam, Gender, and Social Change (New York: Oxford University Press, 1998); Wadud, Quran and Women.

43 Abou-Bakr, "Islamic feminism?". 
şekilde İslam tarihi ve yorumları üzerinde de yeni alternatifler sunan çalışmalar yapılmaktadır. ${ }^{44}$ Ataerkil bakış açısının hâkim olduğu ve toplumsal algılayışların daha fazla sirayet ettiği İslam Hukuku sahasında ise Zainah Anwar ve Kecia Ali gibi yazarlar çalışmalar yapmıştır.

\section{İslamcı Feminist Söylemin Sınırları ve Vadettikleri}

Müslüman kadın düşünürlerin çalışmalarının İslamcı feminizm başlığı altında toplanması bir dizi sorunu beraberinde getirmiştir. Bilhassa bu kadın yazını ile ilgili yapılmış olan tanımlamalar beklentilerin yönünü değiştirmiş ve bu yazının özgünlüğünü de gölgelemiştir. İslamcı feminizme yöneltilen eleştiriler, bu yeni söylemin bir feminizm olup olmadığı konusunda kuşkuları yansıtmaktadır. Zira feminist bir perspektiften dile getirilmesi beklenen kimi yaklaşımlar bu söylemde kırılmaya uğramaktadır. Bununla birlikte eleştirilerdeki hâkim tavır oldukça paradoksaldır; kendilerini ve çalışmalarını tanımlamada edilgen kılınan Müslüman kadın düşünürler, gelenekçi düşünürler tarafından feminizmin temel argümanlarını çalışmalarında kullandıkları, seküler feministler tarafından ise yeterince feminist olmadıkları için eleştirilmektedir. Bu, Müslüman kadın söz konusu olduğunda belirginleşen çelişkili tutumun en önemli göstergelerinden biridir. Bu tutumun farkında olmak, bir meta-anlatıya dönüşmüş batılı feminizmin gölgesinde kalan ve batıdışı toplumlarda gelişen özgün kadın yazınlarını inceleyebilmek için önemli bir başlangıç sunabilir.

İslamcı feminizm/feminist ifadeleri, bu söyleme katkı yapan kadınlar tarafından üretilmemiş, başlangıçta pek çok kadın düşünür bu kullanımlara itiraz etmiş ancak zaman içinde bu tanımlara karşı çıkmaktan vazgeçmişlerdir. Bu tanımların kullanımı zaman içinde bir olguyu tespit etmenin ötesine geçmiş, beklentileri şekillendirmiş ve beraberinde pek çok sorunu getirmiş görünmektedir. İslamcı feminist kabul edilen yazarlar, İslami çevrelerde feminizmi Kur'an'a uydurmaya çalıştıkları ve Kur'an'ı bir kadın hakları dokümanı olarak gördükleri iddialarıyla eleştirilmiştir. ${ }^{45}$ Öte yandan İslamcı feminist söylem teorik bir çerçeveden yoksun olduğu için de eleştiril-

\footnotetext{
44 Abou-Bakr, "Islamic feminism?".

45 Moghadam, "Islamic Feminism and Its Discontents"; Ghada Osman, "Back to Basics: The Discourse of Muslim Feminism in Contemporary Egypt", Women and Language 26/1 (2003): 73-79.
} 
mektedir. Darvishpour, İslamcı feminist söylemin bir kurtuluş hareketini teşvik edemediğini, aksine ataerkil yapılarla uzlaştı̆̆ını iddia etmekte, Mojab ise İslamcı feminist söylem için çalışan batılı ve İranlı feministleri oryantalist bir dünya görüşü içinde çalıştıkları için eleştirmektedir. ${ }^{46}$ Faruqi ve Tohidi gibi düşünürler ise bu söyleme yeni hedefler çizerek bu tür sorunları aşmaya çalışmışlardır. ${ }^{47}$ Faruqi İslami çevrede başarılı olacak bir feminist söylemin farklı sorunları, çözümleri ve amaçları olan yerli bir forma dönüşmek zorunda olduğunun altını çizmiştir. ${ }^{48}$

İslamcı feminist söylemde batılı feministlerin aileye yönelttikleri sert eleştiriler kırılmaya uğramıştır. Seküler Müslüman kadın düşünürler, kadın bedeni konusunda batıdaki yaklaşımlara daha yakın görüşler dile getirmişlerse de aile kurumu bağlamında kadınerkek rollerini tartışmayı tercih etmişlerdir. Buna göre aile kurumu içinde kadın ve erkeğe verilen rollerin sabit olmadığı, değişen toplumsal ve kültürel koşullara göre değişebileceği fikrini İslamcı kadın yazarlarla paylaşmaktadırlar. İslamcı kadın yazınında, kadının aile içinde bedeni yoluyla ezildiği yaklaşımından ziyade İslam'ın kadına verdiği hakların kadının elinden alındığı görüşü hakimdir. Yine batılı feminist söylemde kadın bedeni ile ilgili tartışmalarda dile getirilen cinsel özgürlük, kürtaj gibi talepler bu kadın yazınlarında öncelikli konular olmamıştır. Bu nokta, İslamcı feminist söylemdeki temel eğilimin radikal değil reformcu olduğunu göstermektedir.

Son olarak, İslamcı feminist söylemin işaret ettiği kadın yazınlarının feminist teoloji üretme potansiyeline işaret etmek gerekir. Her ne kadar bu söylem, batıdaki feminist teolojilere tam manası ile karşılık gelmese de kadın yazınlarında ele alınan konular teoloji sahası ile yakından ilgilidir. Bununla birlikte Hıristiyan ve Yahudi feminist yaklaşımlar, feminist hareketler içinde daha uzun ve daha yerleşmiş bir yere sahip iken İslamcı feminist söylem daha yeni, hala

46 Mehrdad, Darvishpour, "Islamic Feminism: Compromise or Challenge to Feminism?", Iran Bulletin Middle East Forum Summur Issue (2003): 55-58; Shahrzad Mojab, "Theorizing the Politics of 'Islamic Feminism'", Feminist Review 69/1 (2001): 124-146.

47 Louis L. Faruqi, "Islamic Traditions and the Feminist Movement: Confrontation or Cooperation?"; Islamic Quarterly London 27/3 (1983): 132-139; Tohidi, "Islamic Feminisim".

48 Faruqi, "Islamic Tradition". 
akıcı, tanımlanmamış ve daha tartışmalıdır. ${ }^{49}$ Yine batılı feminist teologlar, kutsal metinleri tarihsel-eleştirel metotla ele alıp metin tenkidi yapmaktadır. Feminist teolojide temel olarak Tanrı'nın ve din dilinin erilliği, Hz. İsa'nın Tanrı-insan tasavvurunun erkek egemenliğine etkisi ve bu bağlamda kadın-erkek arasındaki ontolojik farkların kurgusu tartışılmaktadır. Müslüman kadın yazınında ise Kur'an metninin sıhhati konusunda bir tartışmanın olmadığı görülmektedir. Müslüman kadın düşünürler çoğunlukla metin tenkidi değil analizi üzerinde yoğunlaşmışlar, din dilinin eril yapısının sorgulanmasının ötesine geçmemişlerdir. Dolayısı ile bu makalede ele alınan kadın yazınlarındaki tartışmaların liberal feminist teolojiye yakın bir çizgide ilerlediğini söylemek mümkündür.

\section{Sonuç}

İslamcı feminist söylem Müslüman kadın düşünürlerin çalışmalarına ve kadın konusundaki eleştirel yaklaşımlarına işaret etmektedir. Bu söylemin üretiminde dini aidiyeti olan kadın düşünürler kadar seküler bir dünya görüşüne sahip düşünürler de yer almaktadır. Ancak bu düşünürleri ve çalışmalarını tanımlamak için kullanılan kavramlar, İslamcı ve seküler Müslüman kadınların görüş farklılıkları belirsizleşmektedir. İslamcı feminist söyleme yöneltilen eleştiriler bu anlamda kısır bir döngünün içine hapsolmaktadır. Zira feminizm olarak nitelendirildiği için bu kadın söyleminde, feminist bir düşüncede olması gerektiği düşünülen unsurlar aranmakta ve yapılan eleştirilerde batılı feminizmin kıstasları kullanılmaktadır. Bu söyleme, feminizmin İslami versiyonu olarak değil feminist eleştirinin üretimlerinden istifade eden görüşler olarak yaklaşmak daha tutarlı bir bakış açısına imkân verebilir. Bilhassa özgün bir teoriden yoksun, daha ziyade analitik bir yaklaşıma sahip olduğu için İslamcı feminist söylemi eleştirel kadın bilinçliliğinin bir örneği olarak görmek daha uygun olabilir.

XIX. yüzyılda ataerkillik belirgin bir toplumsal ve kültürel sorun olarak varlığını devam ettirirken Müslüman kadın ve yaşamı hakkındaki sorunları kökleştiren kimi gelişmeler olmuştur. Özellikle oryantalist ve sömürgeci söylemler kadın bedeninin görünürlüğünü İslam ülkeleri için adeta bir kimlik sorununa dönüştürmüştür. Müslüman kadın ve onun kamusal hayatta görünürlüğü hem batılı ve Müslüman düşünürler hem de Müslüman düşünürlerin

\footnotetext{
49 Tohidi, "Islamic Feminism”.
} 
kendi arasındaki tartışmaların odağına yerleştirilmiştir. Şüphesiz ki bunda kadın yaşamının toplumsal hayat için somut bir veri oluşunun etkisi vardır. Ancak sömürgeci, oryantalist, feminist ve milliyetçi söylemlerdeki temel sorun Müslüman kadını ötekileştirmeleri ve edilgen kılmalarıdır. Bu nedenle İslamcı feminist etiketi altında özgünlügü sorunsallaştırılan eleştirel kadın bilinçliliğini Müslüman kadınların kendilerini temsil hakkını kazanmak için verdikleri mücadelenin bir yansıması olarak görmek daha doğru olacaktır.

Müslüman kadının dindeki ve toplumdaki konumu ile ilgili içeriden bir bakışla yapılan çalışmalar değerlendirilirken aşılması gereken ilk engel genel olarak "öteki" nin, özelde ise batılı feminist söylemin hâkim tavrıdır. Sosyal bilimciler, batı-dışı toplumlarda görülen kadın bilinçliliği örneklerini feminizm olarak tanımlamakta oldukça aceleci davranmaktadır. Bu tanımlama, analitik kolaylık sağlamakla birlikte farklı toplumsal yapılarda görülen olguları oldukları gibi değil de olması beklenildiği gibi görmeye neden olabilmektedir. Klasik feminist teoriler -liberal, Marksist, varoluşçu, radikal vb.-, sıkı sıkıya bağlı oldukları Batı düşünce geleneği, felsefesi ve yaşam biçiminden ayrı düşünülemez. Bu sebeple Müslüman kadın düşünürlerin çalışmalarını feminizm olarak nitelemek üretimlerini değerlendirmede kısıtlayıcı bir bakış açısını beraberinde getirmektedir. Başka bir felsefi-siyasi geleneğe ait bir düşünce sistemi ile tanımlanmak, her ne kadar eleştirel üretimlerinden istifade ediyor olsalar da Müslüman kadınların hem kendilerine bakışlarında hem de kendilerini ifade edişlerinde dar bir alana hapsolma riskini taşımaktadır. Öte yandan, Müslüman kadın düşünürler kadın çalışmalarına yaptıkları katkıları tanımlamak için yeni kavramlar üretmeli ya da en azından İslamcı feminist söylemin sınırlarını kendileri çizmelidirler. Bu yapılmadığ 1 sürece çalışmaları batılı feminizmin gölgesinde kalacak, daha da önemlisi feminist teorilerle sinanmaya devam edecektir. Sonuç olarak, batılı feminist söylemin oryantalist, sömürgeci ve milliyetçi yaklaşımlarla birlikte Müslüman kadınların yeni bir söylem inşa etmelerinde itici bir güç olduğu, bununla birlikte İslamcı feminist söylemin kendi dinamiklerini inşa edebilecek ve özgün eserler vermeye devam edebilecek potansiyele sahip olduğu belirtilebilir. Müslüman kadın düşünürlerin bundan sonraki süreçte bu potansiyelin önündeki engelleri kaldırılmaya yönelik adımlar atmaları ve çalışmalarına gölge düşüren tanımlamalara karşı eleştirel tutumlarını sürdürmeleri oldukça önemlidir. 


\section{Kaynakça}

Abou-Bakr, Omaima. "Islamic feminism? What's in a Name? Preliminary Reflections". Middle East Women's Studies Review 15/4 (2001): 1-4.

Abu-Lughod, Lila. "Do Muslim Women Really Need Saving? Anthropological Reflections on Cultural Relativism and Its Others". American Anthropologist 104/3 (2002): 783-790.

Ahmed, Leila. Women and Gender in Islam: Historical Roots of a Modern Debate. New Haven, London: Yale University Press, 1992.

Aktaş, Cihan. Sistem İçinde Kadın. İstanbul: Beyan Yayınları, 1988. , Mahremiyetin Tükenişi. İstanbul: Nehir Yayınları, 1995.

Ali, Kecia. Sexual Ethics and Islam: Feminist Reflections on Qur'an, Hadith and Jurisprudence. Oxford: Oneworld Publications, 2015.

Ali, Zahra, der. İslamî Feminizmler. Çev. Öykü Elitez. İstanbul: İletişim Yayınları, 2008.

Arebi, Saddeka. "Gender Anthropology in the Middle East". The American Journal of Islamic Social Sciences 2/8 (1991), 99-107.

Arat, Yeşim. "Islamist Women and Feminist Concerns in Contemporary Turkey: Prospects for Women's Rights and Solidarity". Frontiers: A Journal of Women Studies 37/3 (2016): 125-150.

Badran, Margot. “Understanding Islam, Islamism, and Islamic Feminism". Journal of Women's History 13/1 (2001): 47-52.

“Islamic Feminism: What's in a Name?". Al-Ahram Weekly Online 569 (2002): 17-23.

Feminism in Islam: Secular and Religious Convergences. Oxford: Oneworld Publications, 2013.

Barlas, Asma. Believing Women in Islam: Unreading Patriarchal Interpretations of The Qur'an. Austin: University of Texas Press, 2002.

"Engaging Islamic Feminism: Provincializing Feminism as a Master Narrative". Islamic Feminism: Current Perspectives, Ed. Anitta. Kynsilehto, 15-23. Tampere, Finland: University of Tampere, 2008.

Cooke, Miriam. Women Claim Islam: Creating Islamic Feminism through Literature. New York and London: Routledge, 2004.

Çakır, Serpil. Osmanlı Kadın Hareketi. İstanbul: Metis Yayınları, 1996.

Darvishpour, Mehrdad. "Islamic Feminism: Compromise or Challenge to Feminism?". Iran Bulletin Middle East Forum Summur Issue (2003): 55-58.

Donovan, Josephine. Feminist Teori. Çev. Aksu Bora, Meltem Ağduk Gevrek, Fevziye Sayılan. İstanbul: İletişim Yayınları, 2001.

Emin, Kasım. Tahrir'ül Mer'e. Tunus: Darü'l-Maarif, 1990.

Faruqi, Louis L. "Islamic Traditions and the Feminist Movement: Confrontation or Cooperation?". Islamic Quarterly London 27/3 (1983): 132139.

Fidan, Hafsa. Kur'an'da Kadın Imgesi. Ankara: Vadi Yayınları, 2006. 
Göle, Nilüfer. The Forbidden Modern: Civilization and Veiling. Michigan: University of Michigan Press, 1996.

Güç, Ayşe. Feminist Söylemin İslamcı Kadın Yazarlar Üzerindeki Etkisi. Bursa: Uludağ Üniversitesi, Sosyal Bilimler Enstitüsü, Yüksek Lisans Tezi, 2007.

"İslamcı Feminizm: Müslüman Kadınların Birey Olma Çabaları". Uludă̆ Üniversitesi Illahiyat Fakültesi Dergisi 17/2 (2008), 649673.

"Feminist Söylemin İslamcı Kadın Yazınına Etkisi". Kadın/Woman 2000 19/2 (2018), 47-79.

Haddad, Yvonne Y. ve Esposito, John L., eds. Islam, Gender, and Social Change. New York: Oxford University Press, 1998.

Hafez, Sherine. An Islam of Her Own: Reconsidering Religion and Secularism in Women's Islamic Movements. New York and London: NYU Press, 2011.

Halverson, Jeffry R., and Amy K. Way. "Islamist Feminism: Constructing Gender Identities in Postcolonial Muslim Societies". Politics and Religion 4/3 (2011): 503-525.

Hamit, Halil. İslam'da Feminizm. İstanbul: Okumuş Adam Yayınları, 2001.

Hassan, Rifat. "Equal Before Allah? Woman-man Equality in the Islamic Tradition". Harvard Divinity Bulletin 17/2 (1987): 2-14.

"Feminist Theology: The Challenges for Muslim Women". Critique: Journal for Critical Studies of the Middle East 5/9 (1996), 53-65.

"Feminism in Islam". In Feminism and World Religions, Eds. Arvind Sharma ve Katherine K. Youngs, 248-279. Albany: State University of New York Press, 1999.

Hatem, Mervat. "Through Each Other's Eyes: Egyptian, Levantine-Egyptian, and European Women's Images of Themselves and of Each Other (1862-1920)". Women's Studies International Forum 12/2 (1989): 183-198.

Hibri, Azizah Y. Women and Islam. Oxford, New York: Pergamon Press, 1982.

"A Study of Islamic Herstory: Or How Did We Ever Get into This Mess?". Women's Studies International Forum 5/ 1 (1982): 212-215.

"Deconstructing Patriarchal Jurisprudence in Islamic Law: A Faithful Approach". Global Critical Race Feminism: An International Reader, Ed. Adrien Katherine Wing, 221-233. New York: New York University Press, 2000.

Kandiyoti, Deniz. "Contemporary Feminist Scholarship and Middle East Studies". In Gendering the Middle East: Gender, Culture and Politics in the Middle East, Ed. L. Ahmed, M. Cook and S. Sharoni, 1-28. Syracuse, NY: Syracuse University Press, 1996.

Lewis, Pauline. "Zainab al-Ghazali: Pioneer of Islamist Feminism". Journal of History (2007): 1-47. 
İslamcı Feminist Kim? Kavramların Gölgesinde Bir Kadın Söylemi

Mernissi, Fatıma. The Veil and The Male Elite: A Feminist Interpretation of Women's Rights in Islam. Trans. Mary Jo Lakeland. USA: AddisonWesley Publishing Company, 1991.

, Peçenin Ötesi. Çev. Mine Küpçü. İstanbul: Yayınevi Yayıncılık, 1995.

Kadınların İsyanı ve İslami Hafıza. Çev. Aytül Kantarcı. Ankara: Epos Yayınları, 2003.

Mir-Hosseini, Ziba. Islam and Gender: The Religious Debate in Contemporary Iran. Princeton-New Jersey: Princeton University Press, 1992.

Moghadam, Valentine M. "Islamic Feminism and Its Discontents: Toward a Resolution of the Debate". Signs: Journal of Women in Culture and Society 27/4 (2002): 1135-1171.

Moghissi, Haideh. Feminism and Islamic Fundamentalism: The Limits of Postmodern Analysis. London and New York: Zed Books, 1999.

Mojab, Shahrzad. "Theorizing the Politics of 'Islamic Feminism'". Feminist Review 69/1 (2001): 124-146.

Osman, Ghada. "Back to Basics: The Discourse of Muslim Feminism in Contemporary Egypt". Women and Language 26/1 (2003): 73-79.

Rhouni, Raja. Secular and Islamic Feminist Critiques in the Work of Fatima Mernissi, vol. 9. Leiden and Boston: Brill, 2010.

Saadawi, Nevval. Havva'nın Örtülü Yüzü. Çev. Sibel Özbudun. İstanbul: Anahtar Kitaplar, 1991.

Sabbah, Fetna A. İslam'ın Bilinçaltında Kadın. Çev. Ayşegül Sönmezay. İstanbul: Ayrıntı Yayınları, 1995.

Spivak, Gayatri C. "Can the Subaltern Speak". Marxism and the Interpretation of Culture. Der. Cary Nelson ve Lawrence Grossberg, 271-313. Urbana, Chicago: University of Illinois Press, 1988.

Şişman, Nazife. Global Konferanslarda Kadın Politikaları. İstanbul: İz Yayıncilık, 1996.

Tohidi, Nayereh. "Islamic Feminism: Perils and Promises". Middle Eastern Women on the Move, 136-146. Washington: Woodrow Wilson International Center for Scholars, 2003.

Tuksal, Hidayet Ş. Kadın Karşıtı Söylemin İslam Geleneğindeki İzdüşümleri. Ankara: Kitabiyat, 2001.

Wadud, Amina. Quran and Woman: Rereading the Sacred Text from a Woman's Perspective. New York: Oxford University Press, 1999.

Inside the Gender Jihad: Women's Reform in Islam. London: Oneworld Publication, 2008.

Yeğenoğlu, Medya. Sömürgeci Fantaziler: Oryantalist Söylemde Kültürel ve Cinsel Fark. İstanbul: Metis Yayınları, 2003. 